\title{
Public entrepreneurship literature from 2010 to 2019: A systematic review
}

\author{
Ahmed Mohammed, Umaru Mustapha Zubairu, Emmanuel Olayiwola Oni
}

\section{A B S T R A C T}

Objective: The aim of the article is to review some basic issues surrounding public entrepreneurship (PE), as it is perceived as a measure to improve the performance of public organizations.

Research Design \& Methods: This article uses Systematic Assessment Quantitative Technique (SQAT) advanced by Australian researchers (Catherine Pickering and Jason Antony Byrne). It allows the reproduction of verifiable reviews, through geographical, theoretical, and methodological gaps identification in literature. 61 peer-reviewed PE articles from six quality academic databases were systematically reviewed based on the following headings: time and geographical distributions, article type (conceptual or empirical), theories, themes, and methods of data collection.

Findings: The analysis shows that large numbers of PE articles were published in 2016, with more publications in North America and Europe, while Africa has meagre publications. Most of PE articles are conceptually inclined and this suggests more empirical studies be conducted so as to have scientific knowledge of PE adoption. Besides, the study revealed that PE is mostly adopted by federal and state governments across the globe with little or no adoption at the local government level. Significant numbers of PE articles utilized one research method (the survey was dominantly used), future researchers can explore PE studies by merging more research methods to broaden the scope of PE.

Implications \& Recommendations: This study provides a clear picture of what is been investigated and has provided guides for future researchers to widen the knowledge adoption of PE around the globe for better service provision by public stakeholders

Contribution \& Value Added: The study systematically reviewed 61 peer-reviewed PE articles from six quality academic databases (Emerald, Elsevier, Sage, Springer, Taylor \& Francis, and Wiley), thereby facilitating the understanding of PE and providing guides for future researchers of PE around the globe.

\begin{tabular}{lll}
\hline $\begin{array}{l}\text { Article type: } \\
\text { Keywords: }\end{array}$ & research article & \\
JEL codes: & public entrepreneurship; Systematic Assessment Quantitative Technique (SQAT), review \\
\hline \multicolumn{1}{c}{ Received: 17 January 2021 } & Revised: 16 March 2021 & Accepted: 21 March 2021 \\
\hline
\end{tabular}

\section{Suggested citation:}

Mohammed, A., Zubairu, U.M., \& Oni, E.O. (2021). Public entrepreneurship literature from 2010 to 2019: A systematic review. International Entrepreneurship Review, 7(1), 45-58. https://doi.org/10.15678/IER.2021.0701.04

\section{INTRODUCTION}

The concept of public entrepreneurship (PE) has received different notions from different scholars (Hayter, 2015; Klein et al., 2013; Zampetakis \& Moustakis, 2010). It has been perceived from a political or public entrepreneurial perspective to serve as a medium for individuals or group of individuals (public entrepreneurs) to exercising their responsibilities diligently and invent new ideas that will lead to effective service delivery (Diefenbach, 2011; Fuller \& Dellsanti, 2017; Kearney \& Meynhardt, 2016; Klein et al., 2010). It is also viewed as a policy instrument (policy entrepreneurship) that enhances the initiation of activities by the government for improved public sector productivity (Delabbio \& Zeeering, 2013; Hayter, 2015; Klein et al., 2010; Liddle \& McElwee, 2019; Prelipcean et al., 
2014). PE is conceived as corporate entrepreneurship (CE), that is, a combination of political/public entrepreneurial activities and policy entrepreneurship (Diefenbach, 2011; Najmaei \& Sadeghinejad, 2016; Zampetakis \& Moustakis, 2010). To put it differently, CE is equaled to PE (Ćwiklicki, 2017; Diefenbach, 2011; Zampetakis \& Moustakis, 2010) as it entails a collective initiation that leads to the establishment of new institutions or improves on the already existing ones that will pave way for improved public sector productivity and the wellbeing of the citizenry.

PE has become an area of interest to public sector managers in recent times (Zampetakis\&Moustakis, 2010). It is aimed at inculcating innovation in the public sector through efficiency enhancement in the productive process of public institutions (Leyden, 2016,). The practice of PE by developed countries like the United States of America (USA),Germany, the United Kingdom (UK), and China has led to an improvement in the gross domestic product (GDP) and living standards (Delabbio \& Zeemering, 2013; Diefenbach, 2011; Lyon, 2016; Rivera \& Landahl, 2019; Seo \& Chung, 2012) and it instilment in Sweden educational system has led to improved educational standard through proper monitoring and accountability (Gofen \& Blomqvist, 2014). With these benefits derivable from PE, little or no efforts were made for its adoption in the African continent (Dhliwayo, 2017). Hence, the implementation of $\mathrm{PE}$ is dependent on the nature environment and system of government practiced around the globe (Delabbio \& Zeemering, 2013; Rivera \& Landahl, 2019; Seo \& Chung, 2012).

A large number of studies concentrated their investigation of PE at federal and state levels, with little attention given to local governments (Hayter et al., 2018; Lerner, 2010; Lucas, 2017). This is despite the role played by local governments in bringing government closer to the people at the grassroots (Eleni \& Lorraine, 2019). This oversight has been linked to poor management and administration of local governments around the globe (Ali et al., 2019; Delabbio \& Zeemering, 2013; Fuller \& Dellsanti, 2017; Smith, 2012). However, the role of local governments on national development can never be overemphasized (Smith, 2012). It provides social amenities and improves the wellbeing of people at the grassroots (Eleni\& Lorraine, 2019). This calls for researchers, regulatory authority, and stakeholders (elected executives and electorates) to direct their attention to the implementation of PE at all government levels.

This study aims at addressing this research gap on PE by conducting a systematic review of PE research. The papers for this study were sourced from six publishers' databases. That is Emerald, Elsevier, Sage, Springer, Taylor \& Francis, and Wiley. These databases were selected because of their reputation in the publication of peer-reviewed papers. Though, peer-reviewed papers are said to have a high-quality impact as they undergo serious scrutiny in their review process (Bikefe et al., 2020).

This study is time framed as it focuses on articles published between 2010 and 2019. This particular period is chosen to enable the researcher to understand current advances in the area. Life itself is dynamic and human needs change as society grows from one stage to another. The adoption of PE became necessary as wastes are no longer tolerated in the management of public scarce recourse (Diefenbach, 2011; Smith, 2012; Zampetakis \& Moustakis, 2010). Because of this, several matters have been added to the areas of $\mathrm{PE}$, for example, interoperations of public institutions, capabilities of employees, and environmental scanning by public institutions are all considered in the studies of PE (Delabbio \& Zeemering, 2013; Rivera \& Landahl, 2019; Seo \& Chung, 2012).

To achieve the goal of the study, some features of PE were pointed out base on the analytical examination of downloaded papers. The downloaded papers were examined on the following headings: time distribution, geographical distribution, article type (conceptual or empirical), theories, themes, and methods of data collection. The analytical examination of the downloaded papers will help to identify gaps in this area for future researchers to dive into. And for public stakeholders, the gaps will identify their lacking areas for proper challenging of resources.

The remaining part of this paper is outlined as follows: In section 2, literature was reviewed based on previous systematic reviews on PE. This review is different from previous ones as it's all-inclusive and covers more current issues. Section 3 , discusses the method and techniques used in conducting the present study. Section 4, addresses the findings of the study, and also provides research directions for future researchers based on the findings. Section 5 concludes the paper and discusses the limitations of the study and makes suggestions based on the limitations identified. 


\section{LITERATURE REVIEW}

A review of PE literature from the six databases exploited by this review revealed that five systematic reviews were published between 2010-2019 (Ali et al., 2019; Eleni \& Lorraine, 2019; Hayter et al., 2018; Lerner, 2010; Lucas, 2017). While Lerner (2010); Lucas (2017); Hayter et al. (2018); and Eleni \& Lorraine (2019) focused on specific aspects and location of PE research (public policies), only Ali et al. (2019) did a comprehensive review of PE research. Hence, the subsequent paragraphs will discuss these studies.

Lerner (2010) in conducting a systematic review on PE compared Jamaica and Singapore public policies that are geared towards improved economic growth and development. The study was conducted not based on reviewed articles but analyzed statistical data of Jamaica and Singapore from 1965-2006. The study indicated that in 1965, Jamaican gross domestic product (GDP) was $\$ 2,850$ a bit higher than that of Singapore GDP of $\$ 2650$, but four-decade later, Singapore GDP juts to $\$ 31,400$, while that of Jamaica was $\$ 4,800$. The systematic review was focused on the economic comparison between Jamaica and Singapore.

Lucas (2017) in conducting a systematic review of PE reviewed Evidence-Based Policy (EBP) in the USA. EBP is an instrument used in exploring the implementation and evaluation of government policies based on scientific researches. The instrument was used to analyze the "Housing First" for the homeless in the USA. And according to Lucas (2017) in 1984, about 250,000 and above homeless people were estimated by the United States Department of Housing and Urban Development, and the implementation of EBP was used to curtail the number. Though, the focus of this systematic review was specific as it was aimed at examining PE instruments.

Hayter et al. (2018) conducted a systematic review of PE by analytically analyzing the Government Performance and Result Act (GRPA) of 1993 of the USA. The GPRA is an initiation by the government to checkmate the level of responsiveness of public employees to the effective utilization of public resources. The adoption of the GPRA has enhanced accountability and efficiency in government-owned institutions.

Eleni \& Lorraine (2019) in conducting a systematic review of PE research utilized undisclosed case studies from different databases from Greek local governments between 2010-2014. The study was bent on examining inefficiency in Greek local government areas and therefore clamoured for local government reforms. The reforms were aimed at reducing or cutting local government spending and embark on strict supervision of local government activities.

Ali et al. (2019) conducted a systematic review of PE research and focused on the performance of the public sector. The study reviewed 90 English peer-reviewed articles sourced from undisclosed databases. The study was time bond as articles published between 1990-2016 were utilized. The articles were reviewed based on the following PE themes: definition, goals, limitations, influencing factors, and research streams. The earliest article in the systematic review was published in 1990 and the latest was published in 2016. The latest publication year for the articles in the study was 2016 and the study was published in 2019. The systematic review was concentrated on the themes of PE research.

There are little shreds of evidence of systematic reviews of PE studies to the best of this study knowledge. This is because only five systematic reviews of PE articles were found out of which four were policy-based and are limited to a particular locality, and only one was article based. This meagre number of systematic reviews may be because PE researches are just coming up in recent times (Ali et al., 2019).

The most recent systematic review of PE research (Ali et al., 2019) reveals that the researchers concentrated on the themes of PE. The present study conducts a comprehensive review of PE research and its findings will be of utmost importance to the development of localities as it will seek to improve the livelihood of people. The next section will be the methodology of the study.

\section{RESEARCH METHODOLOGY}

This study adopted the Systematic Quantitative Assessment Technique (SQAT) developed by Pickering and Byrne (2013) in conducting its systematic review. The SQAT allows the reproduction of 
verifiable reviews, through geographical, theoretical, and methodological gaps identification in the literature (Pickering \& Byrne, 2013).

According to Pickering and Byrne (2013), SQAT has about 15 stages in undertaking systematic quantitative literature reviews, but five important steps are always recommended for a study. The steps include Topic definition, Research questions formulation, Keywords Identification, Identification and searching of databases, and Reading and assessing publications. Each step and how it was applied in this study is described in Table 1. A total of 61 peer-reviewed English PE articles met the selection criteria from six databases. Table 2 presents the number of articles downloaded from each database utilized.

Table 1. Description and Application of SQAT

\begin{tabular}{|c|c|}
\hline Steps & Application in the current study \\
\hline 1. Define topic & Public Entrepreneurship \\
\hline $\begin{array}{l}\text { 2. Formulate research } \\
\text { questions }\end{array}$ & $\begin{array}{l}\text { Six research questions: } \\
\text { 1. What is the time distribution of PE research articles? } \\
\text { 2. In which countries were these articles written? } \\
\text { 3. What kind of PE articles published? (Conceptual vs. Empirical) } \\
\text { 4. What kind of theories applied in these articles? } \\
\text { 5. What are the specific themes these articles explored, and what were the major } \\
\text { findings in each theme? } \\
\text { 6. What research methods were utilized to conduct the research? }\end{array}$ \\
\hline 3. Identify keywords & Public Entrepreneurship \\
\hline $\begin{array}{l}\text { 4. Identify and search } \\
\text { databases }\end{array}$ & $\begin{array}{l}\text { 1. Six databases utilized: Elsevier; Emerald, Sage, Springer; Taylor and Francis; } \\
\text { Wiley } \\
\text { 2. "All in title" search using the exact phrase: } \\
\text { a. "Public Entrepreneurship" }\end{array}$ \\
\hline $\begin{array}{l}\text { 5. Read and assess } \\
\text { publications }\end{array}$ & $\begin{array}{l}\text { 1. Abstracts of papers found were read to ensure that they were dealing with Pub- } \\
\text { lic Entrepreneurship } \\
\text { 2. Literature reviews, book chapters, and conference proceedings were not in- } \\
\text { cluded; only peer-reviewed conceptual and empirical papers }\end{array}$ \\
\hline
\end{tabular}

Source: own study.

Table 2. Number of Papers Downloaded in Databases

\begin{tabular}{|l|c|}
\hline \multicolumn{1}{|c|}{ Database } & Number of Papers \\
\hline 1. Emerald & 20 \\
\hline 2. Elsevier & 3 \\
\hline 3. Sage & 8 \\
\hline 4. Springer & 15 \\
\hline 5. Taylor \& Francis & 9 \\
\hline 6. Wiley & 6 \\
\hline Total & $\mathbf{6 1}$ \\
\hline
\end{tabular}

Source: own study.

\section{RESULTS AND DISCUSSIONS}

Time distribution of articles on public entrepreneurship (PE)

Figure 1 shows a time distribution analysis of PE research based on this study's sample of 61 articles, published from 2010-2019. The analysis revealed that a peak was reached in 2016 (15 articles), with only one article published in 2011 and six articles published in 2013, 2014, 2015, and 2018 respectively. Articles were published every year between the timeline of 2010-2019. 


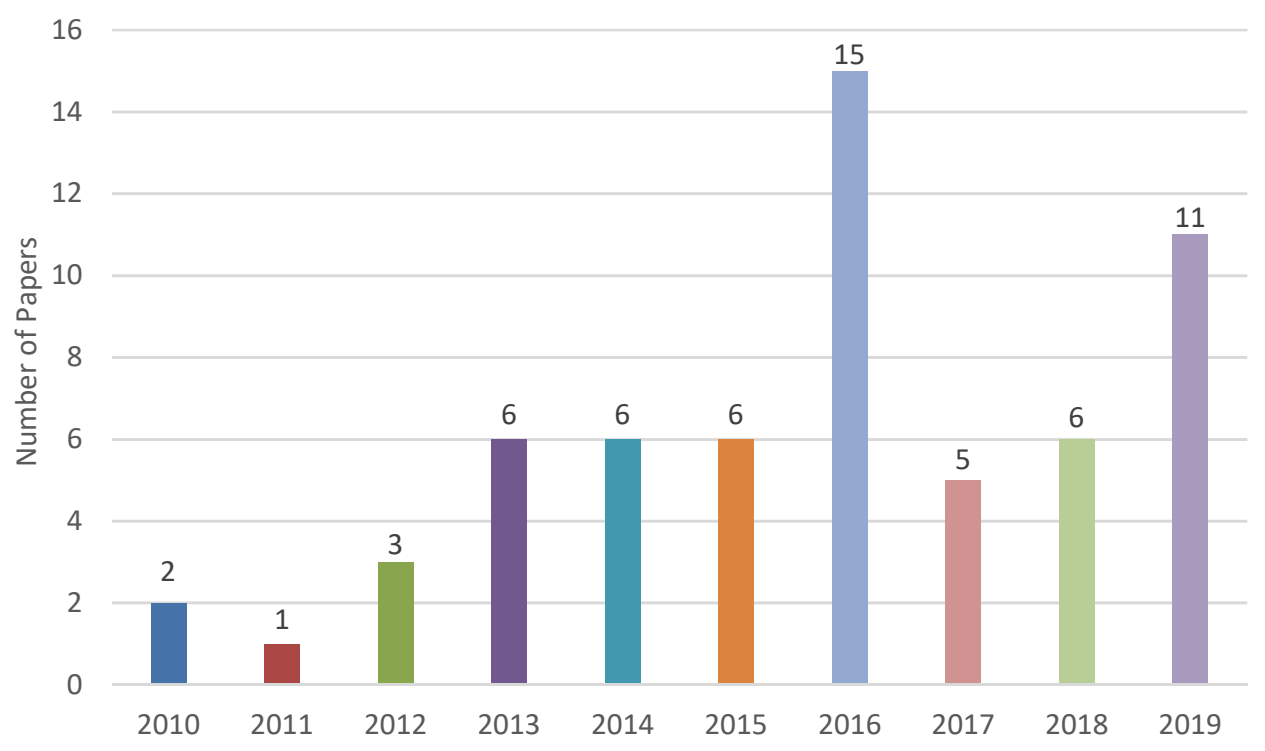

Figure 1. Time distribution of articles on PE from 2010-2019 Source: own elaboration.

\section{Geographical distribution of articles on PE base on continents}

Figure 2 presents the geographical distribution of the 61 PE articles reviewed in this study. It shows that 107 data were obtained from the 61 articles reviewed based on the countries. The analysis revealed the number of data sourced from each continent. The analysis further showed that North America had the highest number of articles published (46), followed by Europe (41), Asia (10), Australasia (5), South America (3), and Africa (2). Africa had the least number of studies in this area, and this reflects a geographical gap in PE research.

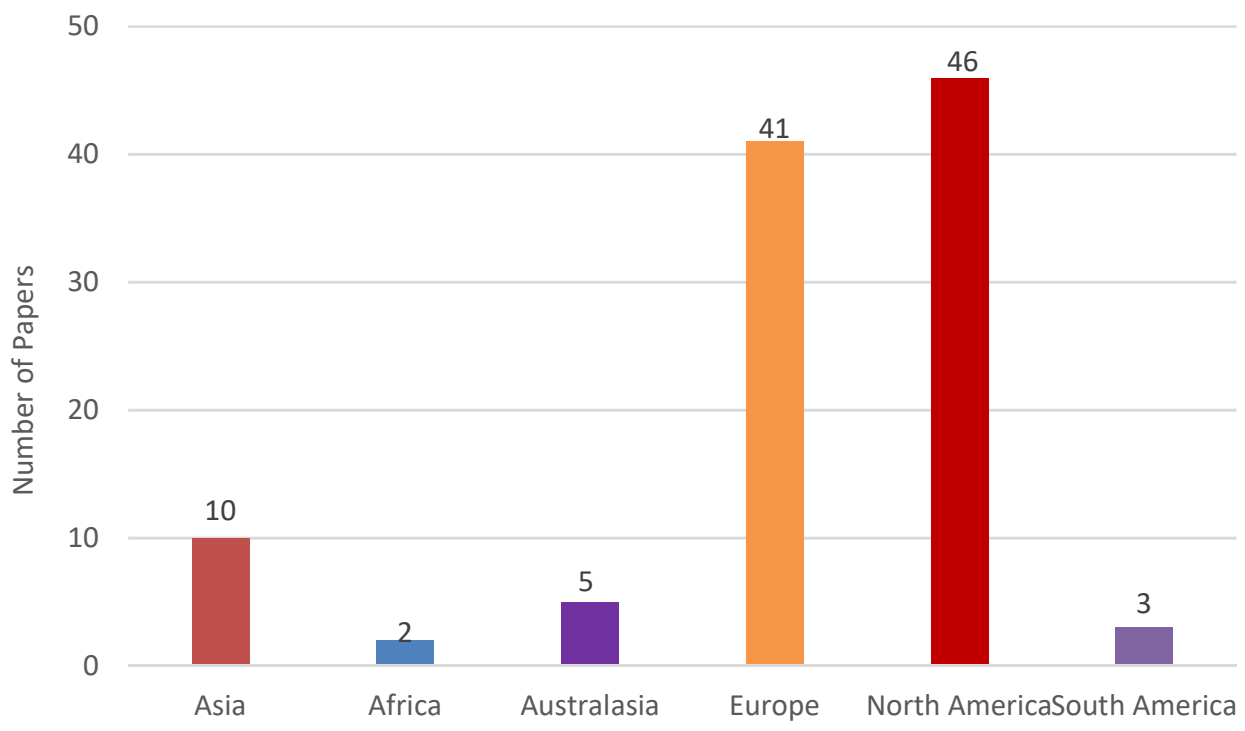

Figure 2. Geographical distribution of articles on PE from 2010-2019 Source: own elaboration.

Africa had been described as one of the underdeveloped continents characterized by inadequate generation and utilization of public resources and outputs (Ndedi \& Antonites, 2015). One of the objectives of public entrepreneurship is to ensure adequate generation and utilization of public resources to fulfil public interest (Dhliwayo, 2017). It would thus be an important avenue for future PE research 
to explore nascent cases of PE in various African countries and to determine their impact in improving the efficiency and effectiveness of African public bureaucracies.

From a country perspective, 23 countries were represented in the systematic review of PE research. Figure 3 presents the top three countries where PE research was conducted. The analysis showed that the United State of America (USA) is the country with the highest number of articles (43), followed by England (21), then Greece (5).

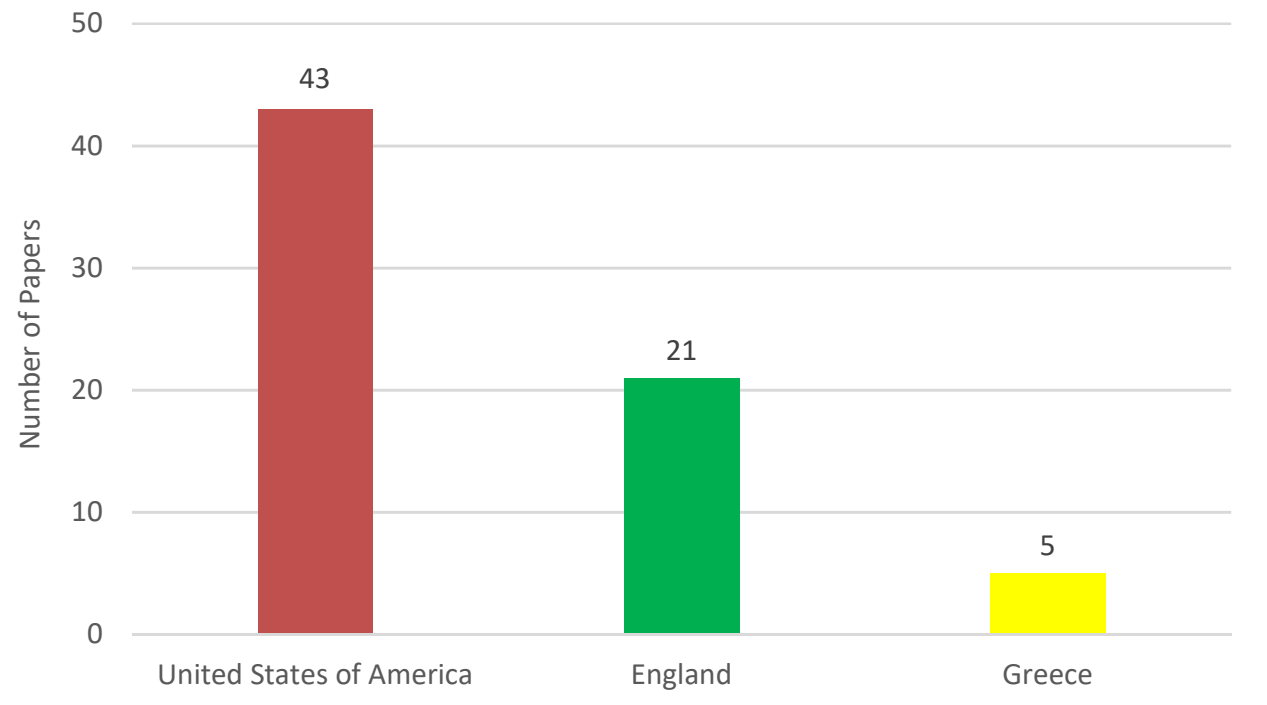

Figure 3. top three countries by research on PE from 2010-2019

Source: own elaboration.

The country analysis showed that 23 countries had published PE research; this number is low when compared with the total number of countries in the world. According to worldatlas.com, there are currently 196 countries in the world, including Taiwan (World Map, 2019). A limitation of this study is its inclusion of only articles published in English. Nonetheless, many countries are not represented in PE research. Considering that citizens of all countries typically rely on the public sector to provide basic services necessary for maintaining the quality of life, $\mathrm{PE}$ has the potential to improve the ways these government agencies use scarce resources to better serve their citizens. For this reason, researchers in every country of the world must holistically investigate PE.

\section{Article type}

Empirical and conceptual articles are the two approaches that are commonly employed while conducting research (Olivia, 2011). Conceptual articles are those that are related to some abstract idea(s) or theories and are generally used by philosophers and thinkers to develop new concepts or to reinterpret existing ones (Bikefe et al., 2020). Empirical articles are those articles that involve data collection and observations. It involves a quantitative analysis of the data collected (Bikefe et al., 2020). Figure 4 shows the breakdown of the 61 PE articles based on the above classification.

Figure 4 indicates that large numbers of the articles reviewed are conceptually inclined (56\%, 34 out of 61 ). The studies tried to provide a better understanding of PE as it tries to promote innovation and efficiency in public bureaucrat organizations for improved service delivery (Lerner, 2010; Wiseman, 2014; Xing et al., 2018). The analysis also showed that there are limited numbers of empirical articles reviewed (44\%). However, because of the limited number of empirical articles on $\mathrm{PE}$, more empirical researches need to be carried out based on the articles reviewed. 


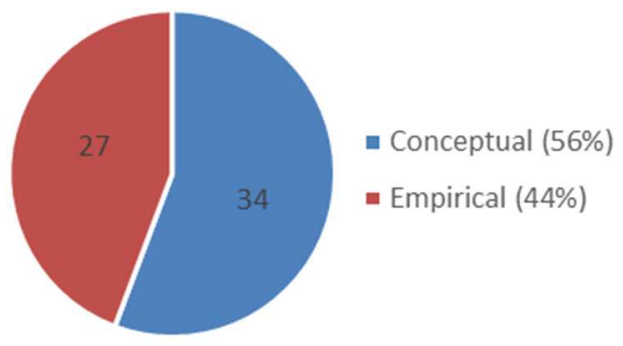

Figure 4. Article type breakdown on PE from 2010-2019 Source: own elaboration.

\section{Theory breakdown}

This study made use of the theories utilized by the 27 empirical articles reviewed for the breakdown (Figure 5). A significant number of papers did not adopt any theory in their analysis (39\%). The top four theories applied in PE are Public Entrepreneurship Theory (14\%), Transaction Cost Economics Theory, Agency Theory and General Theory of Business Modeling has $7 \%$ respectively. The public entrepreneurship theory provides innovative ideas by way identifying and acting on opportunities that will enable proper management of public resources (Carnes et al., 2019; Delabbio \& Zeemering, 2013; Dhliwayo 2017; Diefenbach, 2011; Najmaei \& Sadeghinejad, 2016; Pugalis et al., 2016; Smith, 2012). Transaction costs theory is useful in explicating market, public, and institutional failures, allowing a comparative assessment of imperfect alternatives rather than an unnatural focus on an ideal public outcome (Klein et al., 2010; Pitelis, 2013). The agency theory tries to explain how a dispute between business shareholders and agents (executives) that would disrupt output can easily be resolved in an organization (Klein et al., 2010; Pitelis, 2013). The General theory of business modelling analyses risks identification and the ability of organizations to invest in those risk and rape future benefits (Marie, 2016; Xu \& Carey, 2015).

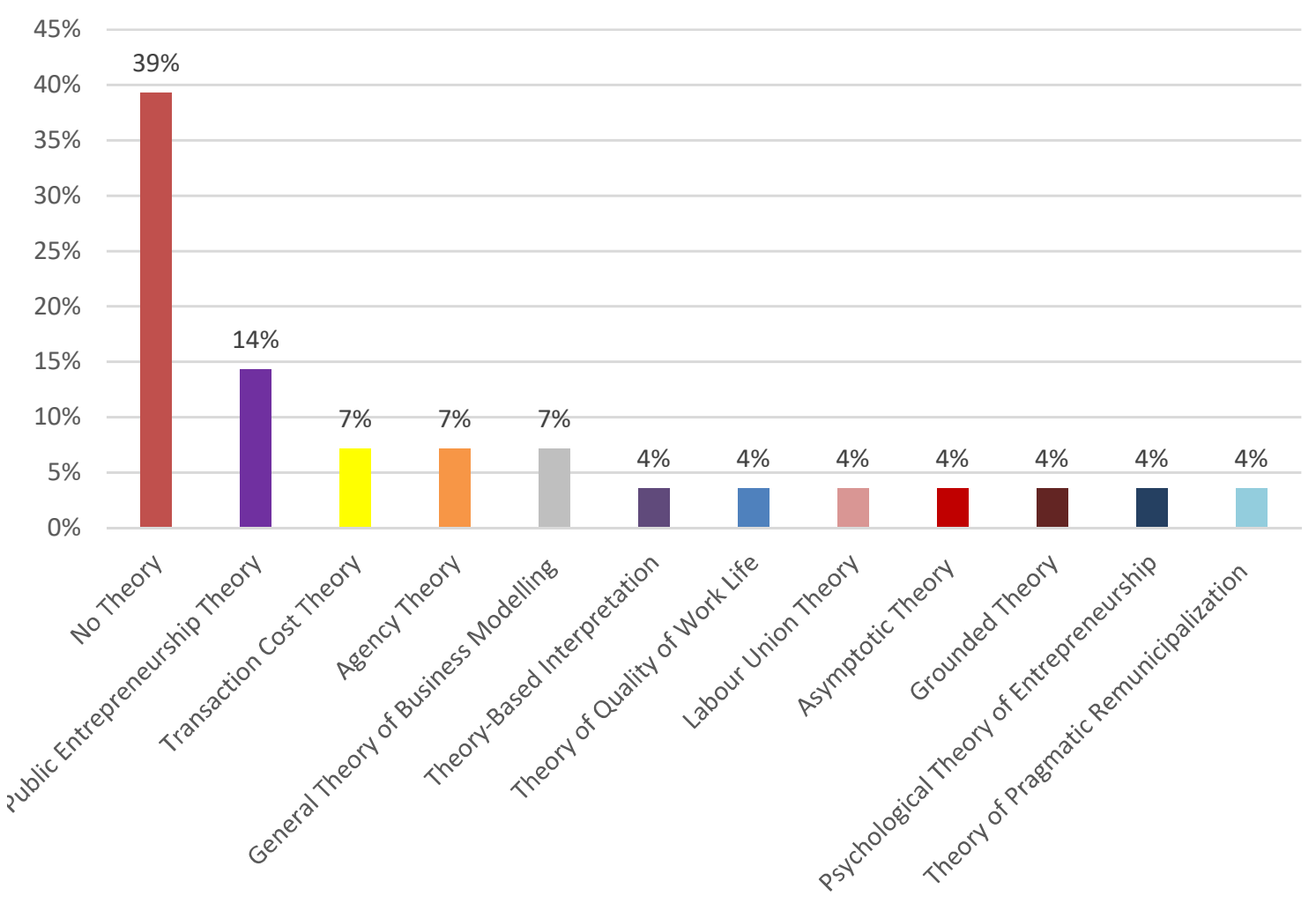

Figure 5. Empirical theory breakdown on PE from 2010-2019

Source: own elaboration. 


\section{PE research themes}

A comprehensive analysis of the $61 \mathrm{PE}$ articles reviewed for this study revealed that they could be classified into three distinct themes: 1) Efficiency in PE (e.g., Xu \& Carey, 2015; Klein et al., 2013; Lee et al., 2012), 2) Employee involvement in PE (e.g., Marie, 2016; Rivera \& Landahl, 2019; Zampetakis \& Moustakis, 2010), and 3) Determinants of PE (e.g., de Andrade et al., 2016; Gofen \& Blomqvist, 2014; Zikou et al., 2017). Figure 6 reveals the number and percentage of the $61 \mathrm{PE}$ articles that make up each category.

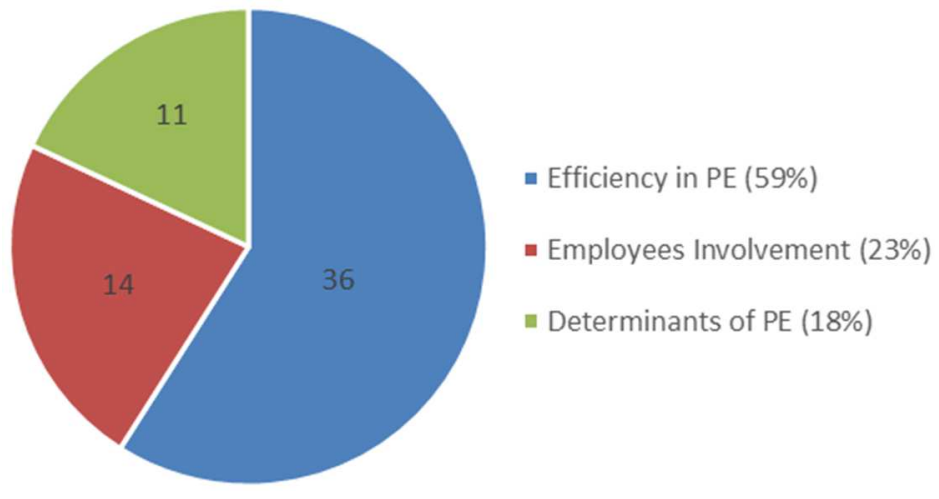

Figure 6. PE Research themes from 2010-2019

Source: own elaboration.

The analysis revealed that the majority of the articles reviewed (59\%) explored efficiency in PE based on the premise that PE can catalyze organizational and regional development (Ali et al., 2019). However, a lack of a business mindset in the public sector was a major reason for its usual bureaucratic and inefficient reputation (Liddle, 2016a; Najmaei \& Sadeghinejad, 2016). However, in recent times, public agencies in countries like the United States of America, Canada, England, and Switzerland have started to adopt PE as a means of improving their efficiencies. It is expected that PE adoption by public agencies will lead to the maximization of public outputs with fewer resources or inputs (e.g. Ali et al., 2019; Cunningham et al., 2016; Dhliwayo, 2017; Klein et al., 2013; Kouakou, 2018; Lee et al., 2012; Lindholst, 2019; Najmaei \& Sadeghinejad, 2016; Xu \& Carey, 2015). However, despite the expected efficiency improvements of PE adoption, some countries have been reluctant to embrace PE in their public agencies (Carnes et al., 2019; Liddle, 2016b; Najmaei \& Sadeghinejad, 2016). Business modelling is described as a logical way an organization creates and captures values. It is a process by which organizations construct and modifies production processes (Najmaei \& Sadeghinejad, 2016).

The next most common theme focused on investigating is employee involvement in the PE process (23\%). It was discovered that employees that worked in entrepreneurial public sector organizations had higher levels of job satisfaction as compared to those working in conventional public sector organizations (e.g., Diefenbach, 2011; Hayter, 2015; Lewis, 2014; Zampetakis \& Moustakis, 2010).

It was also discovered that an important success factor for the success of PE adoption was the involvement of employees in the idea creation and execution phases of projects. This involvement energized and motivated employees to be fully engaged in ensuring that projects were effectively and efficiently completed (e.g., Maranto, 2015; Marie, 2016; Rivera \& Landahl, 2019; Seo\& Chung, 2012).

The last theme amongst the PE themes is PE determinants (18\%), whereby articles sought to understand the factors that determine whether or not a public sector organization adopted an entrepreneurial mindset. These factors were categorized into internal and external factors (Zikou et al., 2017). The internal factors included personal motivation and knowledge, while external factors included the level of economic activities and organization strategy and structure (e.g. de Andrade et al., 2016; Gofen \& Blomqvist, 2014; Smith, 2012; Zikou et al., 2017). Centralization and decentralization of government activates are also said to determine PE in localities (e.g. Beyes, 2015; de Andrade et al., 2016; Delabbio \& Zeemering, 2013; Paik et al., 2018; Strow \& Strow, 2018). Centralization of government leads to concentration of government power and resources on one region of government thereby limiting their 
entrepreneurial adaptability while decentralization, on the other hand, diffuse government resources and enhances interrelation among localities thereby encouraging PE (Rossiter\& Smith, 2017). Additional determinants of PE in localities include barriers to entry and exit for consumers and producers, increased centralization and concentration in government, the lack of residual claim amongst publicsector actors, the rise of public-sector union membership, and increasingly uncompetitive elections.

\section{Data collection methods}

Figure 7 shows that survey was the highest data collection method utilized (43\%) (e.g., Cunningham et al., 2016; Diefenbach, 2011; Hayter, 2015; Zampetakis \& Moustakis, 2010), followed by secondary data (27\%) (e.g. Lee et al.,2012; Pitelis, 2013; Rivera \&Landahl, 2019), interview (20\%) (e.g. de Andrade et al., 2016; Lyon, 2016; Xu \& Carey, 2015) and then observation (10\%) (e.g. Klein et al., 2013; Maranto, 2015; Paik et al., 2018).

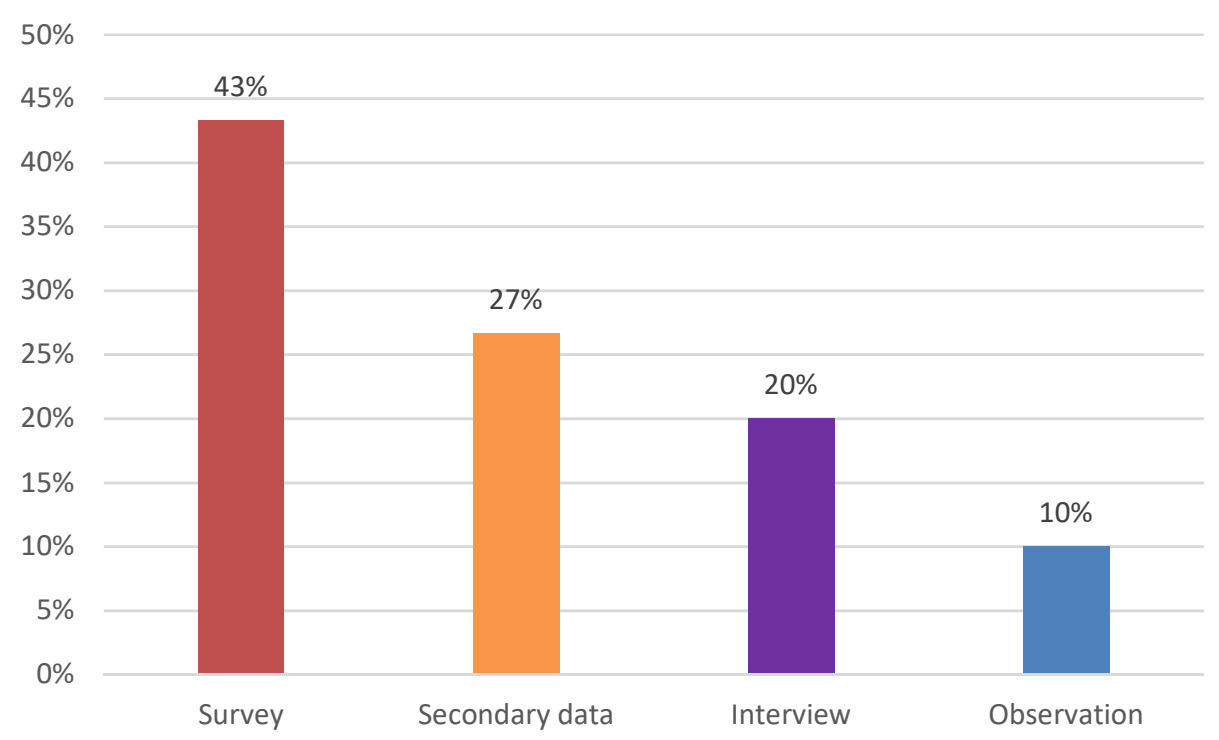

Figure 7. Data Collection Methods Utilized by Empirical Articles Reviewed on PE Source: own elaboration.

The four methods of data collection highlighted in figure 2 had their benefits and challenges. For instance, the survey method can be useful in covering all aspects of a topic from the questions offered to respondents but can lead to dishonest in answering the questions administered (Delabbio \& Zeemering, 2013; Smith, 2012). It is economical to use secondary data because it saves efforts and expenses, though; the accuracy of the data is not known (Lee et al., 2012). Interviews are expected to yield a high percentage of the result as it uses perfect samples from a research population, but it can appear to be costly and time-consuming (Xu \& Carey, 2015).

The observation method is useful in framing hypothesis as researchers easily get acquainted with the phenomenon; the disadvantage with this method is that some occurrences may not be open to observations especially when activities are treated as confidential (Paik et al., 2018). Future researchers on PE can explore the observation method or combination of any of the methods listed in figure 7 since the majority of the studies utilized only one method. 
Table 3. Summary of findings from the 61 reviewed PE articles

\begin{tabular}{|c|c|c|c|}
\hline$S / N$ & Headings & Key Findings & Implications \\
\hline 1 & $\begin{array}{l}\text { Time } \\
\text { distribution } \\
(2010-2019)\end{array}$ & $\begin{array}{l}\text { - There were PE publications in every year of the pe- } \\
\text { riod under review (2010-2019). } \\
\text { - Larger numbers of the publications (15) were made in } \\
2016 \text { and only one publication was made in } 2011 \text {. }\end{array}$ & $\begin{array}{l}\text { - Studies in PE have been captivat- } \\
\text { ing over the past decade. }\end{array}$ \\
\hline 2 & $\begin{array}{l}\text { Geographical } \\
\text { distribution }\end{array}$ & $\begin{array}{l}\text { - } 23 \text { of the countries out of } 196 \text { around the globe have } \\
\text { contributed to researches on PE. } \\
\text { - USA had the highest number of articles (43) pub- } \\
\text { lished on PE. } \\
\text { - Majority of the PE publications (46) amongst the con- } \\
\text { tinents were made by North America, while Africa } \\
\text { had two publications. }\end{array}$ & $\begin{array}{l}\text { - There is need for more researches } \\
\text { on PE around the globe and espe- } \\
\text { cially Africa and South America as } \\
\text { they have the least researches in } \\
\text { this area. }\end{array}$ \\
\hline 3 & Artic & $\begin{array}{l}\text { - Substantial numbers of the articles reviewed are con- } \\
\text { ceptual in nature ( } 34 \text { out of } 61 \text { ), only } 27 \text { are empiri- } \\
\text { cally inclined. }\end{array}$ & $\begin{array}{l}\text { - Empirical studies are required in } \\
\text { the direction as it will provide sci- } \\
\text { entific approach to PE dealings. }\end{array}$ \\
\hline 4 & $\begin{array}{l}\text { Theory } \\
\text { breakdown }\end{array}$ & $\begin{array}{l}\text { - The top most adopted theory in PE researches is the } \\
\text { PE theory (14\%). } \\
\text { - Other adopted theories include transaction cost the- } \\
\text { ory, agency theory and the general theory of business } \\
\text { modeling with seven percent respectively. }\end{array}$ & $\begin{array}{l}\text { - There are no specifications to the } \\
\text { theories to be adopted for PE } \\
\text { studies; hence, scholars are at lib- } \\
\text { erty to adopt theories that best } \\
\text { describes the phenomenon they } \\
\text { are investigating. }\end{array}$ \\
\hline 5 & $\begin{array}{l}\text { PE research } \\
\text { themes }\end{array}$ & $\begin{array}{l}\text { - The review recognized three different PE themes } \\
\text { namely: efficiency in PE, employee involvement and } \\
\text { determinants of PE. } \\
\text { - 59\% of the reviewed articles explored efficiency in } \\
\text { PE, } 23 \% \text { explored employees involvement and } 18 \% \\
\text { were concerned with the determinants of PE }\end{array}$ & $\begin{array}{l}\text { - PE is essential in the economic } \\
\text { transformation of locality as it } \\
\text { helps in the maximization of out- } \\
\text { put in the event of scarce resource } \\
\text { management. }\end{array}$ \\
\hline 6 & $\begin{array}{l}\text { Data collec- } \\
\text { tion meth- } \\
\text { ods }\end{array}$ & $\begin{array}{l}\text { - Four methods of data collection were utilized by the } \\
\text { reviewed articles. } \\
\text { - } 43 \% \text { of the articles reviewed utilized the survey } \\
\text { method, while } 27 \%, 20 \% \text { and } 10 \% \text { of the articles uti- } \\
\text { lized secondary data, interview and observation } \\
\text { methods respectively. }\end{array}$ & $\begin{array}{l}\text { - Future PE scholars can make use } \\
\text { of multiple data collection meth- } \\
\text { ods so as to have better empirical } \\
\text { knowledge of PE. }\end{array}$ \\
\hline
\end{tabular}

Source: own study.

\section{CONCLUSIONS}

This study reviewed 61 peer-reviewed journal articles on PE. The articles were examined based on six key elements: time and geographical distribution of the articles, article type, theories utilized, research themes, and methods. The results from the review were analyzed and discussed to serve as guidance to future PE researchers. However, reasonable numbers of researches have been conducted on PE, but there is more space for empirical researches in the area, especially when considering the role played by PE in fostering economic growth and development in localities around the globe.

There are no researches without limitations, and the limitation of this study will be discussed on the following headings: time-bound, the use of title search, language, and the use of the phrase to search for articles.

Firstly, the study was conducted based on time-bound, that is, only articles published between 2010 and later years were considered. Futures researchers may inculcate earlier years to have more practical ideas.

Secondly, the study used a title search for six databases (Emerald, Elsevier, Sage, Springer, Taylor \& Francis, and Wiley). These databases were recognized in the publication of high-quality peer-reviewed papers. Though they may not cover all peer-reviewed PE articles and with this, future researchers can improve on the scope of databases to broaden PE researches. 
Thirdly, as for language limitation, this study only considered journal articles written in English and excluded books and conference proceedings. This was done to maintain the quality as stipulated by the SQAT methodology. Future researchers can explore books and conference proceedings to widen the knowledge obtainable in PE studies.

Fourthly, the study used phrases for searches in the databases explored rather than keywords. This is because phrases are precise in providing information about PE. Though keyword search is also important, it will provide more articles that may not be directly related to PE for review. And this may distract the researcher from the objective of what is been investigated.

However, despite that limitations discussed highlighted for the study, it is still pertinent to note that this study is relevant as it provides a clear picture of what is been investigated and has provided guides for future researchers to widen the knowledge adoption of PE around the globe for better service provision by public stakeholders.

\section{REFERENCES}

Ali, A., Irfan, S., \& Salman, Y. (2019). An analysis of entrepreneurial perspective of public sector: A systematic literature review from 1990 to 2016. Business \& Economic Review, 11(3), 113-142. DOI: dx.doi.org/10.22547/BER/11.3.5.

Beyes, T. (2015). Fictions of the possible: Art, the city, and public entrepreneurship. Journal of Management Inquiry, 24(4), 445-449.

Bikefe, G., Zubairu, U., Araga, S., Maitala, F., Ediuku, E., \& Anyebe, D. (2020). Corporate Social Responsibility (CSR) by small and medium enterprises (SMEs): A Systematic Review. Journal of Small Business International Review, 4(1), 16-33. https://doi.org/10.26784/sbir.v4i1.243

Carnes, C.M., Gilstrap, F. E., Hitt, M. A., Ireland, R. D., Matz, J. W., \& Woodman, R. W. (2019). Transforming a traditional research organization through public entrepreneurship. Business Horizons, 62(4), 437-449.

Cunningham, J. A., O’Reilly, P., Dolan, B., O’Kane, C., \&Mangematin, V. (2016). Publicly funded principal investigators allocation of time for public sector entrepreneurship activities. Economia e Politicalndustriale, 43(4), 383-408.

Ćwiklicki, M. (2017). Public entrepreneurship and its role in public value creation. Problemy Zarzqdzania, 15(66). DOI:10.7172/1644-9584.5

de Andrade, C. R., Lopes, D.P.T., \& Ckagnazaroff, I.B. (2016). Public entrepreneurship and quality of life: The perspectives of public entrepreneurs from the state of Minas Gerais (Brazil). In J. Leitão \& H. Alves (Eds.), Entrepreneurial and Innovative Practices in Public Institutions, applying quality of life research (pp.41-58). Switzerland: Springer International Publishing. DOI 10.1007/978-3-319-32091-5_3

Delabbio, D.J., \& Zeemering, E.S. (2013). Public entrepreneurship and interlocal cooperation in county government. State and Local Government Review, 45(4), 255-267.

Diefenbach, F. E. (2011). Entrepreneurship in the public sector. In F. E. Diefenbach (Eds.), Entrepreneurship in the Public Sector: when middle managers create public value (pp. 31-64). Germany: Gabler Research.

Dhliwayo, S. (2017). Defining public-sector entrepreneurship: A conceptual operational construct. The International Journal of Entrepreneurship and Innovation, 18(3), 153-163.

Eleni, M., \& Lorraine, J. (2019). Contextualising public entrepreneurship in Greek local government austerity. International Journal of Entrepreneurial Behavior \& Research, 25(7), 1563-1579. https://doi.org/10.1108/ijebr-11-2018-0749

Fuller, C., \&DelliSanti, D. (2017). Spillovers from public entrepreneurship: a case study. Journal of Entrepreneurship and Public Policy.6(1), 72-91. http://dx.doi.org/10.1108/JEPP-03-2016-0010

Gofen, A., \&Blomqvist, P. (2014). Parental entrepreneurship in public education: a social force or a policy problem?. Journal of Education Policy, 29(4), 546-569.

Hayter, C.S. (2015). Public or private entrepreneurship? Revisiting motivations and definitions of success among academic entrepreneurs. The Journal of Technology Transfer, 40(6), 1003-1015.

Hayter, C.S., Link, A.N., \& Scott, J.T. (2018). Public sector entrepreneurship. Oxford Review of Economic Policy, 34(4), 676-694. DOI: 10.1093/oxrep/gry014 
Kearney, C., \&Meynhardt, T. (2016). Directing corporate entrepreneurship strategy in the public sector to public value: Antecedents, components, and outcomes. International Public Management Journal, 19(4), 543-572. DOI: 10.1080/10967494.2016.1160013

Klein, P.G., Mahoney, J.T., McGahan, A.M., \&Pitelis, C.N. (2010). Toward a theory of public entrepreneurship. European Management Review, 7(1), 1-15.

Klein, P.G., Mahoney, J.T., McGahan, A.M., \&Pitelis, C.N. (2013). Capabilities and strategic entrepreneurship in public organizations. Strategic Entrepreneurship Journal, 7(1), 70-91.

Kouakou, T. G. (2018). Public Funds and Entrepreneurship: A Cognitive Economics Approach. Journal of Business \& Economic Policy,5(2). DOI:10.30845/jbep.v5n2p9

Lee, S.M., Hwang, T., \&Choi, D. (2012). Open innovation in the public sector of leading countries, Management Decision, 50(1), 147-162. https://doi.org/10.1108/00251741211194921

Lerner, J. (2010). The future of public efforts to boost entrepreneurship and venture capital. Small Business Economics, 35(3), 255-264.

Leyden, D.P. (2016). Public-sector entrepreneurship and the creation of a sustainable innovative economy. Small business economics, 46(4), 553-564.

Lewis, K.V. (2014). Public narratives of female entrepreneurship: fairy tale or fact? Labour \& Industry: a journal of the social and economic relations of work, 24(4), 331-344.

Liddle, J. (2016a). Introduction: public sector entrepreneurship: key issues, challenges and developments in theory and practice. United Kingdom, UK: Emerald Group Publishing Limited. Retrieved from https://www.emerald.com/insight/content/doi/10.1108/S2040-724620160000006012/full/html.

Liddle, J. (2016b). Conclusion: public entrepreneurship: the future research agenda. United Kingdom, UK: Emerald Group Publishing Limited. Retrieved from https://www.emerald.com/insight/content/doi/10.1108/S2040$724620160000006020 /$ full/html

Liddle, J., \& McElwee, G. (2019). Theoretical perspectives on public entrepreneurship. International Journal of Entrepreneurial Behaviour \& Research, 25(6), 1308-1320. https://doi.org/10.1108/IJEBR-0219-0067

Lindholst, A.C. (2019). Addressing public-value failure: remunicipalization as acts of public entrepreneurship. Journal of Economic Policy Reform, 1-18. https://doi.org/10.1080/17487870.2019.1671192

Lucas, D.S. (2017). Evidence-based policy as public entrepreneurship. Public Management Review, 20(11), 16021622. DOI: 10.1080/14719037.2017.1412115

Lyon, F. (2016). Pushing enterprise and entrepreneurship in the delivery of rural public services: the case of education and health services. United Kingdom, UK: Emerald Group Publishing Limited. Retrieved from https://www.emerald.com/insight/content/doi/10.1108/S2040-724620160000006009/full/html.

Maranto, R. (2015). Did the teachers destroy the school? Public entrepreneurship as creation and adaptation. Journal of School Leadership, 25(1), 69-101.

Marie, T.T. (2016). Public values as essential criteria for public entrepreneurship: Water management in France. Utilities Policy, 40, 162-169.

Najmaei, A., \&Sadeghinejad, Z. (2016). Toward a theory of business models and business modeling in public entrepreneurship. New Perspectives on Research, Policy \& Practice in Public Entrepreneurship, 6, 77-102.

Ndedi, A.A., \&Antonites, A. (2015). Fostering Entrepreneurship in the Public Sector for Economic Development in Africa. Retrieved from https://ssrn.com/abstract=2575025

Olivia, K. (2011). Difference between conceptual and empirical. Retrieved from https://www.differencebetween.com/difference-between-conceptual-and-vs-empirical/

Paik, Y., Kang, S., \& Seamans, R. (2018). Entrepreneurship, innovation, and political competition: How the public sector helps the sharing economy creates value. Strategic Management Journal, 40(4), 503-532.

Pickering, C., \& Byrne, J. (2013). The benefits of publishing systematic quantitative literature reviews for PhD candidates and other early-career researchers. Higher Education Research \& Development, 33(3), 534-548. https://doi.org/10.1080/07294360.2013.841651

Pitelis, C. (2013). Capabilities and strategic entrepreneurship in public organizations. Strategic Entrepreneurship Journal, 7(1), 70-91. 
Prelipcean, R.D., Islam, M.N., Peebles, A., Barakat, T., \& Yao, J. (2014). The impact of public sector entrepreneurship in international education on skilled migration. United Kingdom, UK: Emerald Group Publishing Limited. Retrieved from https://www.emerald.com/insight/content/doi/10.1108/S1479-3679(2013)0000023014/full/html

Pugalis, L., Davidson, J., McLeay, F., \& Round, A. (2016). Tough times, difficult choices and public entrepreneurship: Is sponsorship a winning solution? United Kingdom, UK: Emerald Group Publishing Limited. Retrieved from https://www.emerald.com/insight/content/doi/10.1108/S2040-724620160000006002/full/html.

Rivera, J.D., \& Landahl, M.R. (2019). An environment conducive to bureaucratic innovation?: Exploring the potential for public entrepreneurship within FEMA. Journal of Urban Management, 8(2), 272-281.

Rossiter, W., \& Smith, D.J. (2017). Institutions, place leadership and public entrepreneurship: Reinterpreting the economic development of Nottingham. Local Economy, 32(4), 374-392.

Seo, J., \& Chung, S. (2012). Impact of entrepreneurship in the public sector: Cheonggye stream restoration project in the Seoul metropolitan city. Asia Pacific Journal of Public Administration, 34(1), 71-93.

Smith, E. (2012). Explaining public entrepreneurship in local government organizations. State and Local Government Review, 44(3), 171-184.

Strow, B., \& Strow, C. (2018). Institutional barriers to productive public-sector entrepreneurship. Journal of Entrepreneurship and Public Policy, 7(4), 306-319.

Wiseman, A.W. (2014). Internationally comparative approaches to innovation and entrepreneurship in education. United Kingdom, UK: Emerald Group Publishing Limited. Retrieved from https://www.emerald.com/insight/content/doi/10.1108/S1479-3679(2013)0000023019/full/html.

World Map. (2019). How Many Countries are in the World? Retrieved from http://www.worldatlas.com/ nations.htm.

Xing, Y., Liu, Y., \& Cooper, S.C.L. (2018). Local government as institutional entrepreneur: Public-private collaborative partnerships in fostering regional entrepreneurship. British Journal of Management, 29(4), 670-690.

Xu, J., \& Carey, R. (2015). Post2015 Global Governance of Official Development Finance: Harnessing the Renaissance of Public Entrepreneurship. Journal of International Development, 27(6), 856-880.

Zampetakis, L.A., \&Moustakis, V.S. (2010). An exploratory research on the factors stimulating corporate entrepreneurship in the Greek public sector. International Journal of Manpower, 31(8), 871-887.

Zikou, E., Varsakelis, N., \&Sarri, A.K. (2017). Does public sector crowd out entrepreneurship? Evidence from the EU regions. International Journal of Entrepreneurial Behavior\& Research. 24(4), 866-881. 


\section{Authors}

The contribution share of authors is as follows: Ahmed Mohammed $-40 \%$, concepts of the article and literature review; Umaru Mustapha Zubairu - 30\%, research methodology as well as results and discussions; Emmanuel Olayiwola Oni - 30\%, conclusion and references.

\section{Ahmed Mohammed}

PhD Student at Department of Entrepreneurship \& Business Studies, Federal University of Technology, Minna, Niger State, Nigeria. Works at the Micro \& Small Tax Audit Division of the Federal Inland Revenue Service of Nigeria, Minna Office, Niger State. His research interests focus on Economics, Public Entrepreneurship and Public Finance.

Correspondence to: Ahmed Mohammed, Federal Inland Revenue Service of Nigeria, Micro \& Small Tax Audit Division, Minna Office, Niger State. E-mail: muahmad06@gmail.com

ORCID (1) http://orcid.org/0000-0001-8750-5981

\section{Umaru Mustapha Zubairu}

Senior Lecturer, PhD in Accounting, Works at the department of Entrepreneurship \& Business Studies, Federal University of Technology, Minna, Niger State, Nigeria. His research interests focus on accounting, entrepreneurship and business administration.

Correspondence to: Dr. Umaru Mustapha Zubairu, Federal University of Technology, Minna, Niger State, Nigeria, Department of Entrepreneurship \& Business Studies, e-mail: uzubairu@gmail.com ORCID (1) http://orcid.org/0000-0001-9498-233X

\section{Emmanuel Olayiwola Oni}

Professor of entrepreneurship, Works at the department of Entrepreneurship \& Business Studies, Federal University of Technology, Minna, Niger State, Nigeria. His research interests focus on business administration, entrepreneurship and management.

Correspondence to: Prof. Emmanuel Olayiwola Oni, PhD, Federal University of Technology, Minna, Niger State, Nigeria, Department of Entrepreneurship \& Business Studies, e-mail:olayiwolaoni1@gmail.com ORCID (1) http://orcid.org/0000-0001-8679-278X

\section{Conflict of Interest}

The authors declare that the research was conducted in the absence of any commercial or financial relationships that could be construed as a potential conflict of interest.

\section{Copyright and License}

This article is published under the terms of the Creative Commons Attribution - NoDerivs (CC BY-ND 4.0) License http://creativecommons.org/licenses/by-nd/4.0/ 